\title{
A magyar víziközmü-szolgáltatók integrációja jogi nézőpontból
}

\author{
vízjog - víziközmü-szolgáltatások - integráció - müködési engedély
}

\begin{abstract}
Napjainkban zajlik a magyarországi víziközmü-szolgáltatók számának csökkentése, más megközelítésben, integrációja. A 2012-ben kezdetét vett folyamat jelen állás szerint a szolgáltatók korábbi, megközelítőleg 400-ra tehető számát majd egytizedére csökkentette. E tanulmány keretei között arra teszünk kísérletet, hogy megvizsgáljuk a folyamat hátterében rejlő indokokat, a folyamat jogi kereteit és jövőbeni lehetséges kimenetelét. Mindezen célokat - egy, a téma jobb megértését szolgáló bevezető részt követően - a víziközmü-szolgáltatók müködési engedélyének megszerzésére irányuló eljárás tapasztalatainak elemzésén keresztül igyekszünk elérni. Fontosnak tartjuk kiemelni, hogy jelen tanulmány egy több éve megkezdett kutatás része, amelynek részeredményeit, megállapításait, az ezeket alátámasztó érvelések logikai láncolatát ${ }^{1}$ nem kívánjuk megismételni, ugyanakkor értelemszerüen támaszkodunk azokra. Tekintettel arra, hogy a szolgáltatók integrációja, illetve a víziközmü-szolgáltatásokhoz kapcsolódó egyéb átalakítások még nem fejeződtek be, az azokra vonatkozó következtetések levonása még több szempontból csak esetleges lehet. Végezetül utalunk arra, hogy az integráció finanszírozásának értékelését a Vízkeretirányelv költségmegtérülés elvének vonatkozásában egy másik, párhuzamosan megjelenő tanulmányban fejtjük ki.
\end{abstract}

\section{A tématerület elhelyezése}

A víziközmü-szolgáltatásokra - ezeken e tanulmány keretei között tipikusan a víziközmü-szolgáltató által közszolgáltatási jogviszony keretében nyújtott közmủves ivóvízellátást, illetve a közműves szennyvízelvezetést és szennyvíztisztítást értjük vonatkozó jogszabályi rendelkezések újragondolása nem pusztán magyar sajátosság. Az integratív vízgazdálkodás és vízvédelem témakörébe ágyazva a víziközmü-

* Dr. Szilágyi János Ede egyetemi docens, Miskolci Egyetem ÁJK Agrár- és Munkajogi Tanszék, civdrede@ uni-miskolc.hu. A kutatás a TÁMOP-4.2.4.A/2-11/1-2012-0001 azonosító számú Nemzeti Kiválóság Program - Hazai hallgatói, illetve kutatói személyi támogatást biztosító rendszer kidolgozása és működtetése konvergenciaprogram címú kiemelt projekt keretében zajlott. A projekt az Európai Unió támogatásával, az Európai Szociális Alap társfinanszírozásával valósul meg.

1441 Lásd különösen SzıLÁGYı János Ede: Vízjog - Aktuális kihívások a vizek jogi szabályozásában. Miskolc, Miskolci Egyetem, 2013, 163-214. 
szolgáltatások átszervezése számos más - köztük több európai - ország számára jelent aktuális politikai, gazdasági és jogi kihívást. ${ }^{2}$ A globális szintű kihívásokhoz ${ }^{3}$ ugyanakkor az egyes országok vonatkozásában számos lokális probléma is társul. ${ }^{4}$

A víziközmű-szolgáltatások újraszervezéséhez, mint rendkívül összetett témához, természetesen számos, egymással szorosan összefüggő kérdéskör kapcsolódhat: a fenntartható - egyúttal szükségszerüen integratív - vízgazdálkodás-vízvédelemkatasztrófavédelem, a vízhez való jog, ${ }^{5}$ a víz értékének meghatározása (avagy a víz ára), ${ }^{6}$ a vízszektor és a közszféra-magánszféra szerepvállalása, amely utóbbi kérdéskörnek szintén több megközelítése vetődhet fel: a vízszektor liberalizációja (deregularizációja) - privatizációja vagy éppen szorosabb szabályozása (regu-

2 A terület jogi szabályozásával foglalkozó hatalmas nemzetközi szakirodalom mellett a terület magyar kutatói is szép számban járultak hozzá tevékenységükkel a vizek jogi szabályozásának értékeléséhez. A teljesség igénye nélkül az utóbbi évekből fontosnak tartjuk kiemelni a következőket. Pump Judit: $A$ jog hatása a fenntartható közszolgáltatásra a hulladékgazdálkodás és a vízgazdálkodás területén, PhD-értekezés (kutatóheIyi vita verziója). Budapest, Eötvös Loránd Tudományegyetem Állam- és Jogtudományi Doktori Iskola, 2011; BELÉNYESI Pál: A vízszolgáltatások hatékonyságának javitása a Vízkeretirányelv egyes rendelkezései és a szennyező fizet elvének tükrében, PhD-értekezés. Debrecen, Debreceni Egyetem Marton Géza Állam- és Jogtudományi Doktori Iskola, 2013; SzAPpanyos Melinda: Víz és jog - A vízhez való jog érvényesíthetősége az ENSZ keretében. Veszprém, Veszprémi Humán Tudományokért Alapítvány, 2013; GREKSzA VeronikaSzABó Marcel (szerk.): Right to Water and the Protection of Fundamental Rights in Hungary. Pécs, PTE ÁJK Európa Központ, 2013.

3 A vízhez kapcsolódó nemzetközi szintű szakpolitikai dokumentumok és stratégiák szintén nagy számban állnak rendelkezésre; ezek elemzéséről lásd például SzILÁGY: Vízjog, i. m., 25-40. Jelentőségénél fogva ugyanakkor fontos utalni a Milleniumi Fejlesztési Célok (MDGs) 7.C számú célkitűzésére, amely alapján 2015-ig a felére kívánják csökkenteni azoknak az arányát, akik nem juthatnak hozzá, hogy egészséges ivóvizet igyanak, illetve hogy hozzájussanak az alapvető higiéniai szolgáltatásokhoz; a MDGs teljesítésének aktuális állapotáról lásd http://www.un.org/millenniumgoals/environ.shtml.

4 A vízhez kapcsolódó magyar és európai uniós szakpolitikai dokumentumok és stratégiák elemzéséről lásd SZILÁGYI: Vízjog, i. m., 40-57; valamint a legfrissebb dokumentumok vonatkozásában SzILÁGYI: Az EU és Magyarország vízstratégiája, Publicationes Universitatis Miskolcinensis. Sectio Juridica et Politica, Tomus XXXI, 2013, 475-497.

5 A téma feldolgozásának magyar irodalmához lásd különösen SzappanYos: i. m., 9-130; Fodor László: A víz az Alaptörvény környezeti értékrendjében. Publicationes Universitatis Miskolcinensis Sectio Juridica et Politica, Tom. XXXI., 2013, 342-345.; GrekszA-Szabó (szerk.): i. m., 1-67, 84-227; Kardos Gábor: A vízhez való jog. Acta Humana 2004/1, 93-98; Kecskés Gábor: A vízhez való jog nemzetközi jogi koncepciója. Állam- és Jogtudomány, 2009/4, 569-598; RAIsz Anikó: A vízhez való jog egyes aktuális kérdéseiről. In CsÁK Csilla (szerk.): Jogtudományi tanulmányok a fenntartható természeti erőforrások témakörében. Miskolc, Miskolci Egyetem, 2012, 151-159; SzILÁGYI: Vízjog, i. m., 215-217.

6 A magyar jogirodalom kapcsán lásd különösen BELÉNYESI: i. m., 80-117, 237-244.

7 A magyar jogirodalom kapcsán lásd különösen HoRvÁTH M. Tamás: Közszolgáltatás, magánszerveződés privatizáció a településeken. Magyar Közigazgatás, 1997/4, 197; Uö: Közszolgáltatás, magánszerveződés - privatizáció a településeken. Magyar Közigazgatás, 1997/5, 258. (A privatizáció meghatározásán jelen tanulmány keretei között elfogadjuk Horváth M. Tamás utóbbi munkájában található meghatározást, amely szerint „közszolgáltatások terén privatizációnak nevezzük azt a folyamatot, amelynek során [a] a közjavak magánjószágokká válnak, illetve [b] a magánszektor a közigazgatás megbízásából lát el közfeladatot, vagy egyébként közösségi érdekeltségü feladatot végez.") BELÉNYESI: i. m., 118-157. 
larizációja) - államosítása, ${ }^{8}$ illetve (re)municipalizációja9 ${ }^{9}$ stb. A magyar jogalkotó mindazonáltal alapvetően egy gazdasági-pénzügyi orientációjú, a korábban fennáló víziközmű-szabályozás dilemmáira reflektáló megközelítést alkalmazott.

2011 decemberének végén az Országgyúlés törvényben (továbbiakban: Vksztv. ${ }^{10}$ ) döntött a víziközművek szabályozásának megújításáról (sok elemét tekintve a szabályozás megteremtéséről), amely szabályozásra már hosszú idő óta nagy igény mutatkozott. ${ }^{11}$ A szabályozás, amely egyes előírásait tekintve több időpontban lép, lépett hatályba (legtöbb érdemi rendelkezése 2012. július 15. napjától él, a legfontosabb végrehajtási rendeleteként nevesíthető 58/2013. [II. 27.] sz. kormányrendelet - továbbiakban: Vhr. - pedig 2013. március 1. napjától), komoly előrelépést jelent, nemcsak a víziközmü-ágazat fenntartható müködése szempontjából, de azon

8 A magyar jogirodalom kapcsán lásd különösen HoRVÁTH M. Tamás-PÉTERI Gábor: Nem folyik az többé vissza - Az állam szerepének átalakulása a víziközmü-szolgáltatásban. In Kıss Ferenc László-NAGY Csongor István-VALENTINY Pál (szerk.): Verseny és szabályozás - 2012. Budapest, MTA KRTK Közgazdaság-tudományi Intézet, 2013, 177-200; SzILÁGYI: Vízjog, i. m., 163-214. A szakirodalomban elhangzik azon érv, amely szerint a magánszektor jobban tudja működtetni a víziközmüveket (lásd pl. Belényesi); ugyanakkor számos modern kutatás az Egyesült Államokban arra mutat rá, hogy a közszféra és a magánszféra által működtetett vízgazdálkodás hatékonysága között kicsi a különbség; a kutatásokat hivatkozza AYLWARD, BruceBURCHI, Stefano-Popp, Christie: Water resource quantity: allocation and management. In AyLWARD, BruceBARTRAM, Jamie-PoPP, Christie-VAPNEK, Jessica (szerk.): Law for water management: a guide to concepts and effective approaches, FAO Legislative Study 101. Róma, FAO, 2009, 154-155. Van ugyanakkor olyan szerző is, aki szerint a közjavak privatizációja és a kormányzati szabályozás nélkül is lehet jól működtetni a természeti erőforrásokat mint közösségi forrásokat, a használó emberek vezetésével - OstRom, Elinor: Governing the Commons - The Evolution of Institutions for Collective Action. Cambridge, 1990, Cambridge University Press, 31-33.

9 Municipalizáción jelen tanulmány keretei között azt értjük, amikor (szükebb értelemben) helyi önkormányzat tulajdonába kerül a víziközmű, vagy (mintegy tágabb értelemben) amikor a víziközmű működtetésében a helyi önkormányzati szerepvállalás aránya nő. Remunicipalizáció pedig amikor a helyi önkormányzat viszszaszerzi a víziközmü tulajdonjogát, avagy a müködtetése feletti rendelkezési jogot. A Public Services International Research Unit (PSIRU) legutóbbi kiadványa az utóbbi 15 év föbb remunicipalizációit veszi számba (Magyarországról Kaposvár, Pécs és Budapest esete kerül nevesítésre; egyéb ügyek kapcsán lásd még SzILÁGYI: Vízjog, i. m., 188-194). A PSIRU-anyag a remunicipalizáció legföbb indokaként a következőket nevesíti: (a) az egyes országokra és a szabályozási rendszerekre tekintet nélkül fellépő széles körű problémák a víziközmü-privatizáció kapcsán; (b) a közszféra által üzemeltetett víziközművek ugyanolyan vagy nagyobb hatékonysága, valamint a privát szféra túlzott profitjának eltörléséből eredő alacsonyabb ár; (c) a közszféra viszonylagos előnye a vízhez való jog megvalósításában és az egyéb szociális és környezetvédelmi célok elérésében - HALL, David-LOBINA, Emanuele: List of water remunicipalisations worldwide - As of November 2013, PSIRU University of Greenwich, 2013. 11. 30., http://www.psiru.org/sites/default/files/2013W-Remunicipalisationswater.pdf (2014. 01. 21.).

10 Vagyis a víziközmü-szolgáltatásról szóló 2011. évi CCIX. törvény.

11 Így az egységes víziközmű-szabályozás kialakítását szorgalmazta a JNO 319/2010. sz. állásfoglalás a regionális vízművek átszervezésével kapcsolatos vizsgálatról, 8., 11-12; a JNO 83/2010. sz. állásfoglalás a Gyula-Városerdő településrészének ivóvíz-szolgáltatásával kapcsolatos vizsgálatról, 10.; az Állami Számvevőszék: Jelentés a vizek védelmének és a vízgazdálkodási feladatok ellátásának ellenőrzéséről. 1049. számú jelentés, 2011. február, 28-29.; a Nemzeti Környezetvédelmi Program 2009-2014, a 96/2009. (XII. 9.) Ogy. határozat melléklete (továbbiakban NKP 2009), 90-91; SoмLYódy László (szerk.): Magyarország vízgazdálkodása: helyzetkép és stratégiai feladatok. Köztestületi Stratégiai Programok. Budapest, Magyar Tudományos Akadémia, 2011, 55-57; Koskovics Éva-UngváRI Gábor: Áttekintés a magyar víziközmü-ágazatról. In KIss Ferenc László-NAGY Csongor István-VALENTINY Pál (szerk.): Verseny és szabályozás 2010. Budapest, MTA Közgazdaságtudományi Intézet, 2011, 327. 
jóval túlmutatva a magyar államiság, a nemzeti önrendelkezés szempontjából is. $E$ hangzatos megállapítások kapcsán természetesen joggal vetődik fel a kérdés, hogy mi volt a probléma a korábbi időszak szabályozási környezetével. Az előző időszak szabályozásának részletes bemutatását mellőzve röviden a következő magyarázatot adhatjuk a felmerült kérdésre.

A terület egyes elemeit több jogszabály is szabályozta korábban, így pl. a Kvt12 és a Vgtv..$^{13}$ A korábbi szabályozás kapcsán ugyanakkor számos szabályozandó kérdéskörben nem tartalmazott előírásokat, így pl. hiányzott a víziközmü-szolgáltatási tevékenység hatósági felügyelete és több más garanciális elem is. ${ }^{14} \mathrm{~A}$ szabályozás alapján az ivóvízellátás stratégiai kérdéseiről alapvetően a helyi önkormányzatoknak kellett dönteniük (érthető módon erre nem mindegyik önkormányzat volt alkalmas ${ }^{15}$ ); ráadásul az önkormányzatok - indokolatlanul és sok szempontból összeférhetetlenül - egyszerre több szerepben is jelen voltak a víziközmü-szolgáltatásokkal kapcsolatban: úgymint a közművek tulajdonosai, a víziközmű-szolgáltatások megrendelői, a fogyasztói érdekek közéleti képviselői, fogyasztók, a szolgáltató társaság tulajdonosai/részvényesei, árhatóság (adott esetben mind egyszerre). ${ }^{16}$ Ezen önkormányzati szerephalmozásnak is köszönhető, hogy a víziközmüszektorban rendre elmaradtak a szükséges fejlesztések ${ }^{17}$ - pl. a keresztfinanszírozásnak betudhatóan - amit jól szemléltet az a két adat is, amely szerint (a) a vízveszteség országos átlaga $19 \%{ }^{18}$ (de van olyan adat is, amely ezt a veszteséget $35 \%$-ra teszi! ${ }^{19}$ ), továbbá (b) a „vízellátó hálózatok esetében a rekonstrukcióra érett vezetékhálózat aránya megközelítően 75\%-os, ami mintegy 2000 milliárd forintnyi beruházási igényt jelent". ${ }^{20}$ Ezeken túl az ágazatban egy elaprózódott szerkezet vált jellemzővé (meg-

12 Vagyis a környezet védelmének általános szabályairól szóló 1995. évi LIII. törvény.

13 Vagyis a vízgazdálkodásról szóló 1995. évi LVII. törvény.

14 A Vidékfejlesztési Minisztérium vízügyért felelős államtitkára egy 2010. július 30-án kelt, a jövő nemzedékek országgyűlési biztosának írt levelében jelezte: a korábbi szabályozás legfőbb hiányossága, hogy a szolgáltatás nyújtása vonatkozásában külön engedélyt nem kellett kérni, így ezt a tevékenységet szinte bárki elláthatta; idézi a 319/2010. sz. JNO állásfoglalás, 7.

15 Konkrét ügyek kapcsán lásd pl. JNO J/3869/2008. sz. állásfoglalás a Nagyvejke, folyékony hulladék kezelés és egyéb jogi problémák ügyében, 16; JNO 49/2010. sz. állásfoglalás a balatonszepezdi ivóvízhálózat állapotával kapcsolatos vizsgálatról, 2-3; JNO 83/2010. sz. állásfoglalás, 10; az alapvető jogok biztosának 813/2012. jelentése a gödöllői egyetem hálózati vízellátásáról és az ivóvízbázisok védelméről.

16 BÁNKı Erik: Az állam, az önkormányzatok és a víziközmü-szolgáltatók kapcsolata, avagy A víziközmü-ágazat a ,jogalkotó” szemével. A víziközmű-szolgáltatásról szóló törvényről rendezett konferencia, [Budapest] 2012. február 6.; Az önkormányzatok több vonatkozásban sem voltak alkalmasak a közművek vonatkozásában rájuk rótt feladatok ellátására; erre a következtetésre jut BoLvÁRı Zoltán: Az önkormányzati közüzemi szervezetek privatizációja. Magyar Közigazgatás, 1997/1, 53-54.

17 Somlyódy (szerk.): i. m., 33.

18 Lásd Vízgyüjtő-gazdálkodási Terv - a Duna-vízgyüjtő magyarországi része (VGT), 2010. április, 39. Szintén a víziközművek leromlott állapotára hívta fel a figyelmet a Gazdasági Versenyhivatal (GVH): A hazai víz- és csatornamü üzemeltetési piac feltárása, a víz- és csatornaközmüvek árazási, árszabályozási gyakorlatának vizsgálata. Budapest, GVH Versenykultúra Központ - Expert Management Consulting Kft, 2008. december 15., 5 .

19 Az adatot hivatkozza a GVH, i. m., 123. Más forrás 20-25\%-ot jelöl: Somlyódy (szerk.): i. m., 36-37.

20 „Ugyanezek az értékek szennyvízelvezetés esetében a hálózatok kora miatt kedvezőbben alakulnak. A szennyvízelvezető hálózatokra vonatkozó becsült rekonstrukciós költség körülbelül 200 milliárd forint”; Nemzeti Víztechnológiai Platform: Stratégiai Kutatási Terv - 2010, 27. 
közelítőleg 400 víziközmü-szolgáltatóval, amelyek közül a 35 legnagyobb cég látta el a fogyasztók $85 \%$-át; ${ }^{21}$ a rendszerváltást megelőzően egyébiránt 33 víziközmüszolgáltató müködött ${ }^{22}$ ), és problémát okozott az is, hogy meglehetősen hiányosak voltak az információink a magyar víziközművagyon állapotáról (ha történt is ezzel kapcsolatos felmérés egyik-másik ellátási területen, az nem egységes szempontok alapján valósult meg). ${ }^{23}$ Mindezek komoly nehézségeket jelentenek a víziközműszolgáltatások hosszú távú fenntarthatóságában.

A korábbi időszak korrekciójaként 2011-ben megszületett a Vksztv., majd a Vhr., valamint módosításra került a víziközművek üzemeltetéséről szóló 21/2002. (IV. 25.) KöViM rendelet. Mindezeken túl ugyanakkor számos más jogszabály ${ }^{24}$ is fontos szerepet tölt be a terület szabályozásában. Az új víziközmű-szabályozás - amely számos elemében lefedi az ún. települési vízgazdálkodást ${ }^{25}$ - kapcsán a jogalkotó legfontosabb céljai, illetve az ezekhez rendelt legfontosabb eszközei eredetileg a következők voltak:26 (a) Közművek csak nemzeti tulajdonban lehessenek. (b) Csak nemzeti tulajdonban lehessenek az új víziközmü-szolgáltatók [megítélésünk szerint e követelmény nem annyira de iure, sokkal inkább de facto látszik teljesülni]. (c) Müködési engedély bevezetése a víziközmü-szolgáltató tevékenység kapcsán [s ami megítélésünk szerint legalább ennyire jelentős: egy szakmai felügyelet felállítása a Magyar Energetikai és Közmü-szabályozási Hivatal (MEKH) személyében]. (d) Egységes, állami árszabályozás. (e) A keresztfinanszírozás elkerülése és ezáltal a vízdíj egyfajta védelme. (f) A közművek tervszerü felújításának garantálása. (g) A víziközmü-ágazat stratégiai fejlesztésében aktívabb állami szerepvállalás.

A Vksztv. egyes rendelkezései - mint azt korábban említettük - fokozatosan lépnek hatályba. Ezek tükrében 2016-ig a rendszer kiépülésének korszakát éljük, és majd csak ezen átmeneti időszak lejártát követően áll be a véglegesnek tekinthető szabályozás, és várhatóan ekkortól számíthatunk a Vksztv. alapelveinek (költségmegtérülés elve, keresztfinanszírozás tilalma etc.) teljesen megfelelö, fenntartható víziközmű-szolgáltatással.

Jelen tanulmányban a kézirat lezárásakor (2014. február 1.) még folyamatban lévő, víziközmű-szolgáltatói müködési engedélyekkel foglalkozunk, amely engedélyek fontos intézménynek tekinthetők a víziközmü-szolgáltatók integrációja vonatkozásában. S hogy milyen indok(ok) is áll(nak) a víziközmű-szolgáltatók integrációjá-

21 HoRváth Péter: A Magyar Energia Hivatal jelenlegi és jövőbeni szerepe a magyar közmüszolgáltatásban. A víziközmű-szolgáltatásról szóló törvényről rendezett konferencia, [Budapest] 2012. február 6., 10.

22 A rendszerváltást megelőzően még csak 28 ún. tanácsi vízmü és 5 regionális vállalat működött; GVH: i. m., 37; Koskovics-UnGVÁRI: i. m., 309; SomLYódy (szerk.): i. m., 263-264; VGT, 254.

23 VGT, 257-258; SomLYÓdY (szerk.): i. m., 34, 36-37, 57.

24 Lásd pl. a Vgtv.-t, a Magyar Energetikai és Közmű-szabályozási Hivatalról (MEKH) szóló 2013. évi XXII. (sarkalatos!) törvényt, a MEKH eljárása szempontjából irányadó, a közigazgatási hatósági eljárás és szolgáltatás általános szabályairól szóló 2004. évi CXL. törvényt, a villamos energiáról szóló 2007. évi LXXXVI. törvényt, és annak egyes rendelkezéseinek végrehajtásáról szóló 273/2007. (X. 19.) kormányrendeletet; a Vksztv. bizonyos rendelkezéseinek lakossági felhasználókkal szembeni megsértése esetén lásd a fogyasztóvédelemről szóló 1997. évi CLV. törvényt, illetve a fogyasztókkal szembeni tisztességtelen kereskedelmi gyakorlat tilalmáról szóló 2008. évi XLVII. törvényt etc.

14825 SOMLYódY (szerk.): i. m., 32

26 BÁNKI: $i . m$. 
nak hátterében? - A víziközművek működtetésének megszervezése kapcsán olyan egyszerü pénzügyi-gazdasági tételből érdemes kiindulni, mint amelyre a Horváth $M$. és Péteri szerzőpáros is utal, nevezetesen: „A nagy eszközigényü hálózatos szolgáltatások esetében a hatékony üzemméret a költségeket alakító legfontosabb tényező. Már a megkezdett összevonások után, 2012 végére megyénként két-három nagy, legalább ötvenezres felhasználói egyenértékest ellátó víziközmü-szolgáltató jött létre. A közös közmürendszerek kialakitására ösztönöz az is, hogy a törvény alapcéljai között a regionalitás elve fontos helyet foglal el..."27 Az elaprózottságból eredő hátrányok kiküszöbölése, a jobb kihasználtság és a hatékonyság fokozása érdekében több országban is törekszenek a víziközmü-szolgáltatások gazdaságos működtetésének optimális kialakítására, amelynek egyik eszköze lehet a Magyarországon tipikusan integrációként vagy regionalizációként ${ }^{28}$ nevesített folyamat (megjegyzendő ugyanakkor, hogy vannak olyan mértékadónak tekintett szerzők is, akik pedig a folyamatot a monopolizációval összefüggésben tárgyalják ${ }^{29}$ ).

\section{Az integráció az egyes müködési engedélyek tükrében}

A Vksztv. rendelkezése alapján víziközmü-szolgáltatást csak a MEKH által kiadott víziközmü-szolgáltatói müködési engedély alapján lehet végezni. Az engedély kizárólagos jogot biztosít, és kötelezettséget ír elő az engedélyben meghatározott ellátási területen a víziközmü-szolgáltatás nyújtására. Víziközmü-szolgáltatói működési engedélyt az a korlátolt felelősségű társasági vagy zártkörủen müködő részvénytársasági formában müködő gazdasági társaság kaphat, amely az engedély kiadására irányuló kérelemben megjelölt ellátási területre és víziközmű-szolgáltatási ágazatra vonatkozóan rendelkezik üzemeltetési szerződéssel, és megfelel a jogszabályban meghatározott feltételeknek. ${ }^{30} \mathrm{~A}$ Vksztv. az átmeneti rendelkezések között elöírja, hogy a 2013. május 31. napja után víziközmú-szolgáltatói tevékenységet folytatni kívánó gazdasági társaság köteles legkésőbb e határidőig a müködési engedély iránti kérelmet benyújtani a Hivatalhoz. Ezen kérelem jogerős elbírálásáig a 2012. július 15-én müködő, vagy a működését ezen időpontot követően megkezdő víziközmü-szolgáltatást végző gazdálkodó szervezet jogosult a Vksztv. szerint engedélyköteles tevékenységét a Vksztv.-ben elöírtak szerint folytatni. ${ }^{31}$ A MEKH az engedély

27 HoRváth M.-PÉTERI: i. m., 187-188. A költségek sajátosságait tekintve megjegyzendő még, hogy a „víztermelés-szolgáltatás költségeinek 70-90\%-a az állandó költség (amortizáció, fejlesztési hitelek költsége) és csak 10-30\% a változó költség (anyag, energia, munkabér, szállítás). Ennek következtében a teljesítményükben kihasználatlan vízilétesítmények erősen megdrágítják a víztermelés költségeit, gazdaságtalanná teszik üzemi szinten a víztermelés-szolgáltatást." - HEGEdüs József-TönKö Andrea: $A$ víz- és csatornaszolgáltatás alternatív strukturális modelljei és ezek változási irányai Európában és a fejlett világban. Debrecen, MTA-DE Közszolgáltatási Kutatócsoport, kézirat, 4.

28 Hegedüs-TÖNKö: i. m., 13-14.

29 HORVÁth M.-PÉTERI: i. m., 182.

30 Vksztv. 35. § (1)-(2) bek.

31 Vksztv. 82. § (1)-(2) bek. 
kiadását több okból is köteles megtagadni, ${ }^{32}$ ezen feltételek közül pedig kiemelkedik egy, a szolgáltató méretére utaló, s így az integráció egyik alappillérének tekinthető feltétel, az ún. felhasználói egyenértékkel (FE) kapcsolatos előírás, amely mutató kapcsán a víziközmű-szolgáltatónak fő szabály szerint el kell érnie a 150 ezres értéket (a felhasználói egyenértékröl részletesebben lásd alább). A Vhr. rendelkezése alapján a MEKH legalább háromévente ellenőrzi az engedélyben foglalt feltételeknek való megfelelést. ${ }^{33}$

A víziközmü-szolgáltatói müködési engedély elbírálásának eljárása kapcsán a MEKH számos kérdésben dönthet, így például a kiszervezés, az üzemeltetési szerződés, a beszerzési szabályzat ügyében. Amint erre fentebb már utaltunk, a müködési engedély kiadásának fontos feltételét képezi, hogy a szolgáltató rendelkezzen üzemeltetési szerződéssel, azonban a működési engedély és az üzemeltetési szerződés időbeli hatálya (számos okból) egymástól eltérhet. Ezek a víziközmü-üzemeltetési jogviszonyt ${ }^{34}$ rendező, az ellátásért felelős (a helyi önkormányzat, illetve az állam) és a víziközmű-szolgáltató között létrejövő üzemeltetési szerződések többfélék lehetnek; a Vksztv. hatálybalépését követően: ${ }^{35}$ vagyonkezelési szerződés; koncessziós szerződés; vagy bérleti-üzemeltetési szerződés.

Jelen tanulmány kéziratának lezárásáig a 84 mủködési engedély iránt kérelmet előterjesztő víziközmű-szolgáltató közül 46 kapott működési engedélyt. ${ }^{36} \mathrm{~A} \mathrm{MEKH}$ honlapján elérhető víziközmü-szolgáltatói engedélyek ${ }^{37}$ alapján az integráció folyamata vonatkozásában az alábbi föbb megállapításokat tehetjük.

32 Így, ha „(a) a jogszabályi elöirások nem teljesülnek, a jogszabályi feltételek hiányoznak, vagy a kérelmező nem rendelkezik a jogszabályokban meghatározott engedélyekkel, (b) a kérelmező nem teljesíti a jogszabályban meghatározott, víziközmü-szolgáltatás folyamatos, hosszú távú nyújtásához szükséges pénzügyi, gazdasági, technikai, környezetvédelmi feltételeket, vagy nem rendelkezik az ezek teljesítéséhez szükséges müszaki és tárgyi eszközökkel, személyi és pénzügyi erőforrásokkal, (c) a kérelmezö vonatkozásában az 1. melléklet szerinti képlet alapján kiszámitott felhasználói egyenérték nem éri el a 150 ezret, (d) a kérelmező csődeljárás vagy felszámolási eljárás alatt áll, (e) a kérelmező vagy jogelődje víziközmü-szolgáltatói müködési engedélyét a kérelem benyújtását megelőző 10 éven belül a kérelmezőnek felróható okból visszavonták"; Vksztv. 36. §(1) bek.

33 Vhr. 29. §.

34 Vksztv. 2. § 26. pont: „víziközmü üzemeltetése: a víziközmü-szolgáltatás nyújtása céljából a víziközmü-szolgáltató által végzett mindazon tevékenységek összessége, amelyek a jogszabályokban és az üzemeltetési szerződésben elöirt követelmények teljesitése érdekében okszerüen merülnek fel, különösen a víziközmü müszaki értelemben vett napi üzemben tartása, karbantartása és javitása, közüzemiszerződés-kötés, számlázás, ügyfélszolgálat müködtetése".

35 Vksztv. 15. § (2) bek. A már létező üzemeltetési szerződések tekintetében a Vksztv. fontos átmeneti szabályokat állapít meg; lásd Vksztv. 83. § (1)-(3) bek.

36 A MEKH 2013 októbere és 2014 januárja között négy körben adta át a víziközmű-szolgáltatói működési engedélyeket. Az engedélyesek körét lásd a MEKH honlapján: http://www.mekh.hu/adatok-statisztikak-2/ sajto/sajtokozlemenyek-2/821-46-vizikozmu-tarsasag-szolgaltathat-az-orszagban.html (2014. 01. 21.).

37 A kézirat lezárásakor elérhető 18 határozat között nevesítve volt a Szegedi Vízmü Zrt. határozata is, azonban technikai okokból a határozat nem volt letölthető. http://www.mekh.hu/hatarozatok-2/vizikozmuszolgaltatas/mukodesi-engedely-kiadasa-modositasa-visszavonasa.html (2014. 01. 21.). 


\subsection{Tulajdoni kérdések a víziközmü-szolgáltatók integrációjának tükrében}

Az integrációt szolgáló engedélyezési eljárás kapcsán értékelésre kerültek a víziközmúvek, a rendszerfüggetlen víziközműelemek, a működtető vagyon, illetve víziközmü-szolgáltatók bizonyos tulajdoni vonatkozásai is. A 2010-es kormányváltást követően ugyanis a víziközmüvek vonatkozásában mérvadó vagyonelemek tulajdoni kérdései szintén (újra)rendezésre kerültek; az érintett előírások között voltak új szabályok és olyanok is, amelyek már 2010 előtt is a magyar jogrendszer részei voltak. $^{38}$

Bár a múködési engedélyek kapcsán külön nem tértek ki rá, mégis fontos kiemelni, hogy a víziközművek működésének alapját jelentő vízadók (felszíni és felszín alatti vizek) lényegében ${ }^{39}$ a nemzeti vagyon részeként az állam, illetve a helyi önkormányzatok kizárólagos tulajdonában állnak. ${ }^{40}$

A müködési engedélyezési eljárásban ezzel szemben vizsgálták a víziközművek tulajdoni kérdéseit, amely víziközművek kapcsán mind a nemzeti vagyonról szóló 2011. évi CXCVI. törvény (továbbiakban: Nvtv.), ${ }^{41}$ mind pedig a Vksztv. tartalmaz rendelkezéseket. Utóbbi rendelkezéseire hivatkozással sommásan a következőket állapíthatjuk meg: víziközmü kizárólag az állam és települési önkormányzat tulajdonába tartozhat. ${ }^{42} \mathrm{~A}$ Vksztv. (és az Nvtv.) ugyanis egy a rendszerváltás óta fennálló bizonytalan jogi helyzetet hivatott feloldani, amelyben a víziközműelemek tulajdonjogi megítélése, és többek között azok apportálhatósága körül folyt a vita egy a szakirodalom által - közjogi, illetve magánjogi megközelítés ${ }^{43}$ között. Tekintettel arra, hogy a víziközmủ tulajdoni kérdései kapcsán - az eltérő jogi értelmezésből kifolyólag - különböző jogi megoldások születtek a Vksztv. elfogadása előtt (vagyis víziközmúvek az államon és helyi önkormányzatokon túl más személyek tulajdonába is kerültek), ezért a Vksztv. átmeneti szabályok segítségével teremtette meg az általa megkövetelt jogi helyzetet. A Vksztv. a rendezésnek egy erőteljes állami fellépésen alapuló módját választotta: (a) Azon víziközmű, vagy víziközmü létrehozására irányuló beruházás, amely olyan gazdálkodó szervezet tulajdonában áll, amely felett - ide nem értve a munkavállalói résztulajdont - a tulajdoni részesedés egésze

38 A szabályozást folyamatában mutatja be SzILÁGYl: Vízjog, i. m., 63-94.

39 Lásd ugyanakkor, pl. a Vgtv. 6 . § (4) bekezdését az ingatlan tulajdonosának a tulajdonában álló vizeiről.

40 Nvtv. 4. § (1) bek., 5. § (3) bek. d) pont.

41 Nvtv. 4. § (1) bek. (kizárólagos állami tulajdonként nevesíti az Nvtv. 1. mellékletében meghatározott állami tulajdonban álló vízi közműveket), Nvtv. 5. § (5) a) pont (a helyi önkormányzat korlátozottan forgalomképes törzsvagyonaként nevesíti a helyi önkormányzat tulajdonában álló közmüvet).

42 Vksztv. 6. § (1) bek.

43 A problémakör kapcsán különösen a következő jogforrásokat és szakirodalmat tartjuk fontosnak kiemelni a teljesség igénye nélkül: 11/2002. (III. 20.) AB-határozat; a Debreceni Ítélőtábla Gf.II.30.633/2005/3. sz. itélete; az Állami Számvevőszék jelentése a helyi önkormányzatok közüzemi víz- és csatornaszolgáltatási feladatainak és az ehhez kapcsolódó lakossági díjtámogatási rendszer működésének vizsgálatáról (utóvizsgálat), 314. számú jelentés, 1996; a Legföbb Ügyész VLÜ 1747/1996. számú vizsgálati jelentése; BÁNVÖLGYI Beáta: $A$ víziközmü szolgáltatás jelenlegi formái, koncesszió és ágazati jogszabályok alapján ellátandó feladatok, szakjogászi szakdolgozat. Miskolc, ME ÁJK, 2002, 4-15; MAGYAR ViziKÖZmü SzövetsÉG: A víziközmüvagyon társasági tulajdona. Önkormányzat, 2006/11-12, 38-39.; PumP: i. m., 193-195; Uő: Víziközművek a jogértelmezés csapdájában. Magyar Jog 2008/8., 525-530; SzILÁGYI: Vízjog i. m., 79-94. 
a nemzeti vagyonba tartozik, 2013. január 1-jén az ellátásért felelős (vagyis az állam, illetve a települési önkormányzatok) tulajdonába kerül. A tulajdonjog a törvény erejénél fogva ingyenesen, a tulajdonjoghoz kötődő jogokkal és kötelezettségekkel együttesen száll át. (b) Az előbbi esetkör hatálya alá nem tartozó gazdálkodó szervezet $^{44}$ (adott esetben pl. önkormányzati tulajdonban lévő holdingok tagvállalatai), amely eszközei között sajátjaként víziközmúvet vagy víziközmű létrehozására irányuló beruházást tart nyilván, az ellátásért felelőssel azok ellátásért felelős részére történő átruházásáról 2013. október 31-ig - a polgári jog általános szabályai szerint - írásban megállapodik. A szerződő felek az átruházást legkésőbb 2013. december 31. napjáig kötelesek megvalósítani. Ha a felek ez utóbbi esetkörre megjelölt határidőre (vagyis 2013. október 31-ig) nem állapodtak meg, az ellátásért felelős a gazdálkodó szervezettel szemben annak víziközművel, illetve folyamatban lévő beruházással érintett ingatlanára nézve kisajátítást kérhet. Ha az ellátásért felelős települési önkormányzat a kisajátítási jogával 2014. május 31-ig nem élt, az állam kérheti a kisajátítást. ${ }^{45} \mathrm{~A}$ Vksztv. ezen fentebb részletezett - a korábbi közjogi értelmezést alátámasztó - megoldása már csak azért is tűnhet fontosnak, mivel a vízügyekért felelős (korábbi) magyar minisztérium (a Környezetvédelmi és Vízügyi Minisztérium) és a (475/2013. [XII. 17.] Korm. rendelet alapján 2014. január 1. napjától szintén megszüntetett) Nemzeti Fejlesztési Ügynökség állásfoglalása szerint „az Európai Unió akkor biztosít támogatást, ha az EU-s forrásból megvalósuló beruházás - az uniós mintának megfelelően - közösségi (önkormányzati, állami) tulajdonba kerül. Ezért indokolt a víziközmü-vagyon közösségi tulajdoni körben tartása."46

A Vksztv.-ben megfogalmazott tulajdoni modell érvényesítése végett a víziközmüszolgáltatói működési engedélyek elbírálása során a MEKH vizsgálta a víziközművek tulajdoni kérdéseit is. A MEKH a Vksztv. és az Nvtv. rendelkezéseinek megfelelő tényállásként értékelte azon eseteket, amelyeknél az engedélyezési eljárás (közvetett) tárgyát képező víziközművek 100\%-ban az érintett önkormányzatok önálló tulajdonában álltak (például Borsodvíz, ${ }^{47}$ Dél-Pest, ${ }^{48}$ Hajdúkerületi és Bihari Víziközmű

${ }^{44}$ A Fejérvíz esetében az egyik víziközmű-rendszer üzembe helyezése nem történt még meg határidőre. Ezen víziközmű-rendszer vonatkozásában a MEKH nem adta ki a működési engedélyt (több más víziközmürendszer vonatkozásában azonban kiadta). Az ügy érdekessége, hogy az ellátásért felelös önkormányzatok nem tulajdonosai a közmủnek; ugyanakkor a Vksztv. 8. § alapján, amennyiben „a víziközmü nem állami vagy önkormányzati beruházásban jön létre, a beruházó a víziközmü tulajdonjogát a víziközmü üzembe helyezésének időpontjában az ellátásért felelősre” ruházza át. Lásd a MEKH 1968/2013. sz., 2013. 11. 07én kelt határozatát a Fejérvíz Fejér Megyei Önkormányzatok Víz- és Csatornamű Zrt. víziközmű-szolgáltatói müködési engedélyéröl.

45 A települési önkormányzat az MNV Zrt.-t 2014. június 15-ig értesíti, ha kisajátítási jogával nem élt. Lásd Vksztv. 79. §.

46 Az állásfoglalást idézi az Állami Számvevőszék 1049. számú jelentése, 85.

47 A MEKH 1967/2013. sz., 2013. 11. 07-én kelt határozata a Borsodvíz Önkormányzati Közüzemi Szolgáltató Zrt. (a továbbiakban: Borsodvíz) víziközmű-szolgáltatói működési engedélyéről.

15248 A MEKH 1841/2013. sz., 2013. 10. 03-án kelt határozata a Dél-Pest Megyei Víziközmű Szolgáltató Zrt. (a továbbiakban: Dél-Pest) víziközmü-szolgáltatói működési engedélyéröl. 
Szolgáltató Zrt. ${ }^{49}$ Pannon-víz; ${ }^{50}$ ezen esetkör speciális helyzetét képezi az, amikor az érintett víziközművek részben vagy egészben 100\%-ban az érintett önkormányzatok közös tulajdonában állnak, pl. Szolnok ${ }^{51}$ kapcsán), vagy az állam, illetve az érintett önkormányzatok tulajdonában (pl. TRV52) voltak. Mindezeken túl a MEKH találkozott olyan kérelmezőkkel is, amelyek kapcsán a víziközművek tulajdoni kérdéseinek rendezésére még nem került sor a működési engedélyezési eljárásig, vagyis a víziközművek még a gazdasági társaság tulajdonában álltak. Ilyen esetekben (pl. Debrecen $^{53}$ és MIVÍZ ${ }^{54}$ ) a MEKH felhívta az érintett szolgáltatók figyelmét arra, hogy a Vksztv. 6. § (1) bek. alapján víziközmü kizárólag az állam és települési önkormányzat tulajdonában állhat, és hogy a Vksztv. 79. § (2) bek. alapján (a már említett módon és határidőre) a sajátjukként nyilvántartott víziközművek átruházásáról kötelesek megállapodni, és az átruházást 2013. december 31. napjáig megvalósítani, majd pedig az átruházás tényét a MEKH-nek bejelenteni.

A víziközművek tulajdonán túl a működési engedélyek kiadására irányuló eljárásban a MEKH foglalkozott a víziközmü-szolgáltatók tulajdonosi hátterével is. Ezzel kapcsolatban fontos kiemelni mind az Nvtv., mind a Vksztv. előírásait. Az Nvtv. például állami tulajdonként, konkrétan nemzetgazdasági szempontból kiemelt jelentőségü nemzeti vagyonként (s így forgalomképtelenként) nevesíti az Nvtv. 2. mellékletében az 5 regionális vízmủ zrt.-t, és az ezekben való állami részesedés legalacsonyabb mértékét $75 \%+1$ szavazatban állapítja meg. ${ }^{55}$ Ezen regionális víziközmü-szolgáltatókon túl az Nvtv. korlátozottan forgalomképesnek minősítette azon (a nemzetgazdasági szempontból kiemelt jelentőségű vagyon körén kívül álló), állami tulajdonban lévő társasági részesedéseket, amelyek többségi állami tulajdonban

49 A MEKH 1976/2013. sz., 2013. 11. 07-én kelt határozata a Hajdúkerületi és Bihari Víziközmű Szolgáltató Zrt. víziközmü-szolgáltatói müködési engedélyéröl.

50 A MEKH 1969/2013. sz., 2013. 11. 07-én kelt határozata a Pannon-víz Víz- Csatornamű és Fürdő Zrt. (a továbbiakban: Pannon-víz) víziközmü-szolgáltatói működési engedélyéröl.

51 A MEKH 1827/2013. sz., 2013. 10. 03-án kelt határozata a Víz-és Csatornaművek Koncessziós Zrt. Szolnok (a továbbiakban: Szolnok) víziközmü-szolgáltatói működési engedélyéről. Mivel e szolgáltatónál a víziközmű-rendszeren több ellátásért felelős is tulajdonnal rendelkezik, ezért alkalmazandók a Vksztv. 9. § (2)-(3) bekezdései, annak érdekében, hogy meghatározott legyen az ellátásért felelősök képviselete: „A közös tulajdonban lévő víziközmü-rendszerekre nézve az érintett települési önkormányzatok által tett nyilatkozatokból megállapitható, hogy nem került külön kijelölésre az ellátásért felelösök képviseletében eljáró személye, igy a legnagyobb lakosságszámú települési önkormányzat (Szolnok Megyei Jogú Város Önkormányzata) rendelkezik eljárási képviselettel, a Hivatal döntésére a Vksztv. 9. § (3) bek. alapján nincs szükség." Közös tulajdonú helyzet fennáll a Fejérvíz és a Soproni Vízmű bizonyos víziközmű-rendszerei tekintetében is; lásd a MEKH 1836/2013. sz., 2013. 10. 03-án kelt határozatát a Soproni Vízmű Zrt. (a továbbiakban: Sopron) víziközmű-szolgáltatói működési engedélyéröl.

52 A MEKH 1979/2013. sz., 2013. 11. 07-én kelt határozata a Tiszamenti Regionális Vízművek Zrt. (a továbbiakban: TRV) víziközmű-szolgáltatói működési engedélyéről.

53 MEKH 1832/2013. sz., 2013. 10. 03-án kelt határozata a Debreceni Vízmü Zrt. (továbbiakban: Debrecen) víziközmü-szolgáltatói működési engedélyéröl.

54 A MEKH 1833/2013. sz., 2013. 10. 03-án kelt határozata a MIVÍZ Miskolc Vízmü Kft. (a továbbiakban: MIVíz) víziközmü-szolgáltatói működési engedélyéröl. A víziközművek tulajdoni viszonyai kapcsán ellentmondásos megállapításokat tartalmaz ugyanakkor a MEKH 1835/2013. sz., 2013. 10. 03-án kelt határozatának indokolása, a Zempléni Vízmű Kft. (a továbbiakban: Zemplén) víziközmű-szolgáltatói működési engedélyéről.

55 Nvtv. 4. § (2) bek. 
álló (pl. ivóvíz-) közszolgáltatási tevékenységet ellátó gazdasági társaságban állnak fenn. Az Nvtv. értelmében az ilyen, korlátozottan forgalomképes nemzeti vagyon fő szabály szerint kizárólag helyi önkormányzat vagy önkormányzati társulás részére idegeníthető el. ${ }^{56} \mathrm{Az}$ Nvtv. a helyi önkormányzatok vonatkozásában is tartalmaz rendelkezéseket, amelyek szerint helyi önkormányzat korlátozottan forgalomképes törzsvagyonába tartozik a helyi önkormányzat többségi tulajdonában álló, közszolgáltatási tevékenységet ellátó gazdasági társaságban fennálló, helyi önkormányzati tulajdonban lévő társasági részesedés, amely kizárólag az állam, másik helyi önkormányzat vagy önkormányzati társulás részére idegeníthető el. ${ }^{57} \mathrm{~A}$ víziközmü-szolgáltatók esetében a Vksztv. ugyanakkor további szabályokat állapít meg, így például azt, hogy „vagyonkezelési, továbbá bérleti-üzemeltetési szerződés kizárólag olyan víziközmü-szolgáltató társasággal jöhet létre: a) amely kizárólag az ellátásért felelős, vagy rajta kívül az állam, települési önkormányzat, vagy ezek közös tulajdonában áll; b) amely kizárólag az a) pont szerinti gazdasági társaság, vagy rajta kívül az állam, települési önkormányzat, vagy ezek együttes tulajdonában áll". ${ }^{58}$ A Vksztv. ezen jogszabályhelyére hivatkozással a MEKH a TRV néhány, 2012. július 15-ét (vagyis a Vksztv. érdemi rendelkezéseinek hatálybalépését) követően megkötött üzemeltetési szerződését a Vksztv.-be ütközőnek találta, ${ }^{59}$ mivel a TRV által benyújtott üzemeltetési szerződésekkel érintett települési önkormányzatok mint ellátásért felelősök nem rendelkeztek a TRV-ben részesedéssel. Bár a MEKH a TRV-t megfelelő határidő kitűzésével felhívta az ellátásért felelősök tulajdonosi részesedésének igazolására, azonban a TRV e felhívásnak a megadott határidőn belül nem tett eleget, így a MEKH a TRV ezen üzemeltetési szerződéseinek jóváhagyása iránti kérelmét elutasította (fontos kiemelni, hogy a TRV más víziközmürendszerek müködtetése vonatkozásában azonban megkapta a működési engedélyt) azzal, hogy a TRV a MEKH közérdekü üzemeltetőt kijelölő határozatának jogerőre emelkedéséig folytatja az érintett ellátási területeken a megjelölt szolgáltatási ágazat tekintetében a víziközmü-szolgáltatást. E döntéssel egyidejűleg a MEKH eljárást indított a közérdekű üzemeltető kijelölésére. ${ }^{60}$

Az előzőekben említett, víziközművekre, illetve víziközmű-szolgáltatókra vonatkozó tulajdoni kérdéseken túl, a működési engedély kiadására irányuló eljárásban a MEKH foglalkozott egyéb vagyoni elemekkel is - így például az ún. rendszerfüggetlen víziközműelemekkel (amelyek pedig elidegeníthetők a víziközmű-szolgáltató részé-

56 Nvtv. 4. § (4)-(7) bek.

57 Nvtv. 5. § (5), (7) bek.

58 Vksztv. 16. § (6) bek. A jogszabályhely értelmezése kapcsán lásd HoRvÁTH M.-PÉTERI: i. m., 185. Egyébiránt a Vksztv. 16. $\S(7)$ bek. kiegészítésként megállapítja, hogy a (6) bekezdés szerinti társaság holdingba szervezett módon is müködhet.

59 MEKH 1979/2013. sz. határozat rendelkező rész III.2-11. pontok.

60 A híradásokból kiderül ugyanakkor az, hogy „döntött a társaság 300 darab, 10 ezer forint névértékű részvényének értékesítéséről. A vásárlási lehetőséggel minden a cég üzemeltetési területéhez tartozó, köztartozástól mentes önkormányzat élhet, csak egy részvényt vásárolhat, ám tulajdonosi jogokat gyakorolhat"; http://www.hirado.hu/2014/01/11/tovabb-novelte-szolgaltatasi-teruletet-a-tiszamenti-regionalis-vizmuvek$\mathrm{zrt} /(2014.01 .11$.$) .$ 
re) $)^{61}$ és a víziközműnek nem minősülő, víziközmű-szolgáltató által biztosított ún. víziközmü-müködtető eszközökke/ ${ }^{62}$ - terjedelmi okokból azonban erre részleteiben nem térünk ki.

\subsection{A felhasználói egyenérték mint a szolgáltatók méretének minimumstandardja}

Mint korábban utaltunk rá, a víziközmü-szolgáltatók integrációjának, s így a víziközmü-szolgáltatók működési engedélyének egyik sarokpontja a felhasználói egyenérték, amelynek lényege, hogy a víziközmű-szolgáltatónak ezen érték vonatkozásában el kell érnie a 150 ezret. A felhasználói egyenérték egy „olyan mutatószám, amely a víziközmü-szolgáltatást igénybe vevő felhasználók számosságát - víziközmü-szolgáltatási ágazatonként, a felhasználók kapacitásigényeire figyelemmel - az 1. melléklet szerinti képlet ${ }^{63}$ alapján egységesen fejezi ki”. ${ }^{64} \mathrm{~A}$ felhasználói egyenérték - leegyszerüsítve - tehát a víziközmü-szolgáltató méretét hivatott kifejezni a felhasználók számának figyelembevételével. A Vksztv.-ben fő szabályként meghatározott 150 ezres felhasználói egyenérték a szétaprózódott víziközmü-ágazat integrációjának egy nagyon fontos eleme, teljesítése alól ugyanakkor a jogalkotó több vonatkozásban is eltérést engedett. Egyrészt a 150 ezres felhasználói egyenérték el nem érésére tekintettel nem lehet visszautasítani a müködési engedély iránti kérelmet, ha a kérelmező 2011. december 31. előtt megkötött és hatályos üzemeltetési szerződéssel rendelkezik, és a visszautasítás nemzetközi beruházás-védelmi szerződés rendelkezéseibe ütközne (a továbbiakban: beruházás védelmi klauzula). ${ }^{65}$ Másrészt, átmeneti szabályozásként, a MEKH a víziközmű-szolgáltató részére első

61 Lásd Vksztv. 7. §; a rendszerfüggetlen víziközműelem meghatározásáról lásd Vksztv. 2. § 17. pont.

62 Vksztv. 14. §.

63 A képlet alapján (leegyszerüsítve) a felhasználói egyenérték három tétel összege. Az első tétel lényegében a közműves szolgáltatást igénybe vevő lakossági felhasználók száma. A második tétel lényegében a közműves szolgáltatást igénybe nem vevő lakossági felhasználók száma. Míg az első két tétel az ún. közmüfejlesztési hozzájárulásra nem kötelezetteket foglalja magában, addig a harmadik tétel éppen a közmüfejlesztési hozzájárulásra kötelezettekhez kötődik. A harmadik tételnél ugyanis a négyszeresét kell venni a „közmüfejlesztési hozzájárulás fizetésére kötelezettek részére a víziközmü-szolgáltató által közmüves ivóvízellátásra, valamint közmüves szennyvízelvezetésre és -tisztításra biztosított közmüfejlesztési kvóták" összegének. Lásd még Vksztv. 2. § 14. pont (közműfejlesztési kvóta: „víziközmü-szolgáltatásba bekapcsolt vagy bekapcsolni kivánt ingatlanhoz a víziközmü-szolgáltató által a közmüfejlesztési hozzájárulás fizetésére kötelezett részére biztosított vagy biztositandó kapacitás, amelynek mértékegysége: $\left.\mathrm{m}^{3} / \mathrm{nap}^{\prime}\right)$; Vksztv. 69-72. §. és Vhr. 90. §.

64 Vksztv. 2. § 7. pont.

65 Vksztv. 36. § (2) bek. Lásd a külföldiek magyarországi befektetéseiröl szóló 1988. évi XXIV. törvényt, a vonatkozó kétoldalú államközi megállapodásokat és a nemzetközi privatizációs szerződéseket (Washingtoni Választottbíráskodás etc.); SzABó Iván: Üzemeltetési formák és integrációs lehetőségek a Víziközmű törvény hatálybalépését követően. A víziközmü-szolgáltatásról szóló törvényről rendezett konferencia, [Budapest] 2012. február 6., 12-13; lásd továbbá SzEMESı Sándor: Nemzetközi beruházásvédelmi megállapodások és egyezmények. In HoRváth M. (szerk.): Jelenségek - A városi kormányzás köréből. Budapest-Pécs. Dialóg Campus Kiadó, 2013, 173-193. A témához kapcsolódik továbbá az Alkotmánybíróság 14/2013. (VI. 17.) AB-határozata. 
alkalommal legalább 50 ezer felhasználói egyenérték elérése esetén ${ }^{66}$ is kibocsátja a működési engedélyt, amennyiben a víziközmű-szolgáltató a jogszabályi feltételeknek egyébként megfelel (a továbbiakban: az átmeneti mentesülés klauzulája). Ezen esetben, ha a felhasználói egyenérték (a) nem éri el a 100 ezret, akkor a múködési engedélyt 2014. december 31. napjával, (b) ha eléri a 100 ezret, de nem éri el a 150 ezret, akkor 2016. december 31. napjával visszavonja. ${ }^{67}$ Harmadrészt, bizonyos feltételek fennállása esetén, nem kerül figyelembevételre a 150 ezres felhasználói egyenértékre vonatkozó követelmény koncessziós társasággal szemben (a továbbiakban: koncessziós társasági klauzula). ${ }^{68}$

A MEKH eljárása kapcsán a szolgáltatók közül többen már most teljesítették a 150 ezres felhasználói egyenértéket (Dél-Pest, Debrecen, Fejérvíz, MIVÍZ, Pannonvíz, Szolnok, TRV, Zemplén stb.). Többen viszont első körben még nem tudták teljesíteni a fő szabályként elvárt követelményt, és csak korlátozott időre kaptak működési engedélyt. Mindezek mellett ugyanakkor arra is volt példa, hogy a felhasználói egyenérték kapcsán meghatározott követelményeknek való meg nem felelés miatt az engedély kiadására átmenetileg sem került sor. Az imént említett három variáció közül az utóbbi két esetkört tartjuk fontosabbnak körüljárni.

I. A 150 ezres felhasználói egyenértéket nem teljesítette, a koncessziós társasági klauzulára hivatkozással (Vksztv. 27. §) azonban mégis megkapta a működési engedélyt a Cívisvíz. ${ }^{69}$ A vonatkozó jogszabályhely alapján ${ }^{70}$ a Cívisvíz mint koncessziós társaság esetében azért nem került figyelembevételre a 150 ezres felhasználói egyenérték követelménye, mivel a Cívisvíz alapítója, nevezetesen a Debreceni Vízmű Zrt. maga rendelkezik működési engedéllyel, és egyúttal a koncessziós társaság szerződéses kötelezettségeinek teljesítéséért egyetemleges felelősséget vállalt. Az eset részleteire kitérve, elsőként megemlítendő, hogy az eljárás elején tekintettel arra, hogy a Cívisvíz kérelmének benyújtásakor a Debreceni Vízmü Zrt. az egyetemleges felelősséget ugyan vállalta, azonban a Debreceni Vízmű Zrt. mint

66 Úgy tünik, hogy az 50000 FE-t se érte el, tehát nem volt jogszabályi mód arra, hogy a müködési engedélyt ideiglenesen megkapja az esztergomi szolgáltató - a MEKH 1794/2013. sz., 2013. 09. 23-án kelt határozata az Esztergomi Vízmű Szolgáltató és Kereskedelmi Kft. víziközmü-szolgáltatói működési engedély kiadásának megtagadásáról. 18483 FE-vel bírt az oroszlányi vízszolgáltató, így esetében sem volt mód az átmeneti mentesülés klauzulájának alkalmazására - a MEKH 272/2014. sz., 2014. 01. 17-én kelt határozata az Oroszlányi Szolgáltató Zrt. víziközmű-szolgáltatói működési engedély kiadásának megtagadásáról. Pusztán 3524 FE-vel bírt a bábolnai vízszolgáltató, így esetében sem volt mód az átmeneti mentesülés klauzulájának alkalmazására - a MEKH 254/2014. sz., 2014. 01. 17-én kelt határozata a Bábolnai Szennyvízkezelő és Szolgáltató Kft. víziközmű-szolgáltatói működési engedély kiadásának megtagadásáról.

67 Vksztv. 84. § (1)-(2) bek.

68 Vksztv. 27. § (2) bek.

69 A MEKH 1975/2013. sz., 2013. 11. 07-én kelt határozata a Cívis Közüzemi Szolgáltató Kft. (továbbiakban: Cívisvíz) víziközmü-szolgáltatói müködési engedélyéröl.

70 Vksztv. 27. § (2) bek.: „Az engedélyezési eljárásban a koncessziós eljárás nyertesének döntése eredményeként alapított koncessziós társasággal szemben a 36. § (1) bekezdés c) pontja nem kerül figyelembevételre, amennyiben (a) a koncessziós társaságot a 36. § (1) bekezdés c) pontjának figyelembevételével kibocsátott müködési engedéllyel rendelkező víziközmü-szolgáltató alapította, s annak szerződéses kötelezettségei teljesitéséért egyetemleges felelősséget vállalt, vagy (b) közös ajánlattevők esetén, közülük az a) pont szerinti müködési engedéllyel rendelkező víziközmű-szolgáltató is tagja a koncessziós társaságnak, és annak szerződésszerü teljesitéséért egyetemleges felelősséget vállalt." 
alapító, müködési engedély iránti kérelmének elbírálása még folyamatban volt - a MEKH a Cívisvíz egyedüli alapítójának, a Debreceni Vízmű Zrt.-nek a működési engedély kérelme elbírálásáig a Cívisvízre vonatkozó eljárást felfüggesztette. Mivel pedig később az alapító Debreceni Vízmű Zrt. 2013. október 7-én működési engedélyt kapott, így a MEKH a Cívisvíz vonatkozásában az eljárást folytatta. A Cívisvíz müködési engedélye kapcsán fontos ugyanakkor felhívni a figyelmet arra, hogy a koncessziós társasági klauzulára hivatkozás nem mentesít a Vksztv., illetve Vhr. más feltételeinek teljesítése alól. Ez a helyzet következett be ugyanis a Cívisvíznél, és emiatt a Cívisvíz csak feltételes müködési engedélyt kapott. A Vksztv. (és részletesen pedig a Vhr. 31. §) ugyanis nagyon komoly feltételeket támaszt a víziközmü-szolgáltató személyi állományával kapcsolatban is (a jogszabályhelyek ${ }^{71}$ alapján rendelkezni kell föállású munkakörben vízépítő mérnökkel, vegyészmérnökkel, gépészmérnökkel, villamosmérnökkel, környezetvédelmi mérnökkel, biológussal, hidrogeológussal), amely feltételeknek a kisebb szolgáltatók (mint amilyen a Cívisvíz is, amely megközelítőleg 6 ezres felhasználói egyenértékkel rendelkezik, és pusztán egy település, Nádudvar tekintetében nyújt szolgáltatást) csak nagy költségek felvállalásával tudnak eleget tenni. ${ }^{72}$ Mivel a Cívisvíz esetében a MEKH megállapította, hogy a Cívisvíz nem rendelkezik a Vhr. 31. § (3) bek. ca), valamint cd)-ci) pontjaiban megfogalmazott személyi feltételekkel, hiánypótlásra szólította fel a Cívisvízt, bekérve a Vhr. 26. § szerinti felzárkózási tervet ${ }^{73}$ a személyi állomány tekintetében. A Vhr. 26. §-a alapján a MEKH a feltételes engedélyt legfeljebb 12 hónapra adja ki, amely időtartam indokolt esetben egy alkalommal legfeljebb 6 hónappal meghosszabbítható. Mindezen előírásokra tekintettel a Cívisvíz esetében a MEKH a víziközmü-szolgáltatói működési engedélyt 2014. október 31. napjáig adta ki.

II. A 150 ezres felhasználói egyenérték követelményének első körben nem tudott eleget tenni a Borsodvíz sem (a Borsodvíz nyilatkozata szerint ugyanis a müködési engedély megszerzésére irányuló eljárás közben néhány településsel megkötött üzemeltetési szerződése megszűnt, s a felhasználói egyenértéke így lecsökkent 150 ezer FE alá), azonban a működési engedély megszerzésére irányuló eljárás későbbi szakaszában, hivatkozva az átmeneti mentesülés klauzulájára, a hiánypótlás keretében válaszleveléhez egyidejüleg csatolta az ún. integrációs tervét is, annak bemutatására, hogy 2016. december 31. napjáig hogyan tesz eleget a 150 ezres FE érték követelményének. ${ }^{74} \mathrm{~A}$ MEKH ezt követően az integrációs tervben foglaltakat megvizsgálta és megállapította, hogy az abban foglaltak teljesítésével a 150 ezres

71 Vhr. 31. § (3) bek. ca), valamint cd)-ci) pontjai.

72 Ezen megállapítás természetesen nem jelenti azt, hogy a 150 ezres felhasználói egyenértéket meghaladó méretű víziközmű-szolgáltatók esetében nem jelentkezhetnek hiányosságok a személyi állomány vonatkozásában; lásd a Zemplén esetét, amelynél a MEKH azt észrevételezte, hogy a társaság hidrogeológus munkakörben, teljes munkaidőben (csak) 2016. december 31-ig tartó határozott időtartamban alkalmaz 1 fő munkavállalót. A Zemplén feltételezhetően emiatt kapott csak 2016. december 31-ig működési engedélyt.

73 Felzárkózási tervben foglaltak teljesítésére hívta fel a MEKH a Fejérvíz-et is, igaz, nem az ellátási területéhez tartozó összes víziközmü-rendszer vonatkozásában, pusztán a Bicske-Csabdi ivóvíz-szolgáltató rendszer kapcsán, ugyanis a Fejérvíz határidöre nem tudta csatolni az érintett víziközmürendszer vonatkozásában a vagyonbiztosítási igazolást, mivel a vagyonbiztosítás megkötése akkor még csak folyamatban volt.

74 Vhr. 35. §. 
FE érték elérése valószínűsíthető. Mindezekre tekintettel döntött a MEKH a működési engedély 2016. december 31. napjáig terjedő kibocsátásáról. Abban az esetben, ha az integrációs tervben foglaltakat a Borsodvíznek sikerül megvalósítania, és mindezt a MEKH-nek bejelenti, úgy a jövőben a MEKH a működési engedély időbeli hatályát, a müködési engedély alapjául szolgáló üzemeltetési szerződések időbeli hatályának figyelembevételével, hivatalból fogja módosítani.

A MEKH gyakorlatában van ugyanakkor példa arra is, hogy a müködési engedély kiadása iránti kérelmet megtagadja. Ilyen eset állt fenn a Zsigmondy Béla Víziközműveket Üzemeltető Zrt. esetében is, amely eredetileg három település (Hódmezővásárhely, Mindszent és Székkutas) víziközmürendszereinek vonatkozásában terjesztette elő kérelmét. ${ }^{75}$ Ezen ügy bevezetésében érdekességként említjük meg azt, hogy az eljárás során a Zsigmondy részéröl egyébiránt hivatkozás történt a 150 ezres felhasználói egyenérték alóli mentesülésre a - korábban említett beruházásvédelmi klauzula alapján is (ugyanis a Zsigmondy Béla Vízműnél 2006-ig érdekelt volt a Berliner Wasserbetriebe); végül azonban a Zsigmondy az eljárás későbbi szakaszában egyértelmúen úgy nyilatkozott, hogy a beruházásvédelmi klauzula a társaságot mégsem érinti. ${ }^{76} \mathrm{~A}$ beruházásvédelmi klauzula alkalmazásának hiányában pedig a MEKH vizsgálta a Vksztv. által meghatározott felhasználói egyenértéknek való megfelelés szabályait. Hasonlóan a Borsodvízhez, itt is nyilvánvaló volt, hogy első körben a Zsigmondy nem felel meg a 150 ezres felhasználói egyenértéknek (ugyanis megközelítőleg 78500 felhasználói egyenértékkel rendelkezett). Ezt követően a kérdés az volt, hogy a Zsigmondy hosszabb távon meg tud-e felelni a 150 ezres elvárásnak, vagyis hogy esetében alkalmazható-e az átmeneti mentesülés klauzulája. Bár a MEKH éppen nem sokkal a működési engedély megszerzésére irányuló kérelem elbírálása előtt hagyta jóvá Hódmezővásárhely Önkormányzata és a Zsigmondy között létrejött bérleti-üzemeltetési szerződést, ${ }^{77}$ ugyanakkor a MEKH rendelkezésére álló adatok és a Zsigmondy nyilatkozata alapján nyilvánvalóvá vált, hogy a másik két érintett önkormányzat (vagyis Mindszent és Székkutas) az Alföldvíz Regionális Víziközmü-szolgáltató Zrt.-vel (ARV) kíván szerződést kötni. Mindez pedig nagyban kétségessé tette a kérelemhez becsatolt integrációs terv megvalósulását, amely tervben a Zsigmondy előadta, hogy mivel a cég szerződéses felhasználói egyenértéke nem éri el a 100 ezer felhasználói egyenértéket, erre tekintettel már 2012-ben megkezdték az egyeztetéseket a lehetséges integrációról (pl. Szeged, Makó és Csongrád települések víziközmücégeivel), azonban a tárgyalások iránya a Vhr. kibocsátásig bizonytalan volt. Mivel a Vhr. a víziközmü-szolgáltatók szoros 40 km-en belül található - integrációját segítette elő, továbbá tekintettel a Zsigmondy jelentős adósságállományára, a korábbi érdeklődés a Zsigmondyval való integrációs együttműködésekre vonatkozóan megszűnt. Újabb kísérletként 2013. április 5-én a Zsigmondy (ismételt) megkereséssel élt Szeged, Makó, Szentes és Békéscsaba vízmücégei felé, amely megkeresésben gyors cégjogi integrációt kezdeményezett.

75 A MEKH 1332/2013. sz., 2013. 07. 08-án kelt határozata a Zsigmondy Béla Víziközműveket Üzemeltető Zrt. (a továbbiakban: Zsigmondy) víziközmü-szolgáltatói müködési engedélyének megtagadásáról. 
Azonban a megkeresett víziközmű-szolgáltató társaságok egyike sem kívánt élni a Zsigmondy által felvázolt cégjogi integrációs lehetőséggel, aminek az oka az, hogy Makó és Szentes térségének önkormányzatai az ARV-vel kívánnak szerződni, az ARV és a Szegedi Vízmủ Zrt. pedig a Zsigmondy jelentős adósságállománya miatt zárkózott el az egyesülés lehetőségétől. A müködési engedély megszerzésére irányuló eljárás utolsó szakaszában végül a Zsigmondy maga is kijelentette, hogy jelenleg nem tud megnevezni olyan víziközmü-szolgáltató társaságot, mely a Vhr. által rögzített $40 \mathrm{~km}$-es határon belül integrációs törekvéseiben partner lenne. A MEKH határozatának indoklásában kitért rá, hogy a 150 ezer felhasználói egyenérték elérését önmagában nem valószínűsíti a Zsigmondy arra vonatkozó nyilatkozata és valószínűsítése, hogy a társaság eredményességi mutatói, valamint rövid távú gazdasági fejlődése a 40 km-en belül elhelyezkedő vízmücégek számára a jövőben az integráció tekintetében vonzóvá válhat. Mindezekre tekintettel, és mivel a Vhr. 35. $\S(5)$ bek. értelmében a MEKH az integrációs tervet nem fogadhatja el, a MEKH a müködési engedély kiadását megtagadta.

Gondolatmenetünknek ezen a pontján fontosnak tartjuk megemlíteni: a Zsigmondy víziközmú-szolgáltató esete - több más mellett - rámutat arra is, hogy az integráció mikéntjét a jogalkotó az ellátásért felelősök szabad akaratára bízta.

A MEKH tehát megtagadta a Zsigmondy víziközmű-szolgáltatói működési engedélyének kiadását. Mindezen túl azonban rendezésre várt még az érintett települések víziközmü-szolgáltatása. Ennek biztosítása érdekében a MEKH elsőként kötelezte a Zsigmondyt arra, hogy a folyamatos és biztonságos ellátás érdekében az üzemeltetési szerződés megszűnéséig a víziközmü-szolgáltatást és az annak teljesítéséhez szükséges tevékenységeket folyamatosan tartsa fenn. Ezt követően a MEKH egy másik határozatával ${ }^{78}$ (amely határozat indoklásából egyúttal kiderül, hogy a Zsigmondy ellen az adóhatóság felszámolási eljárás megindítását kezdeményezte ${ }^{79}$ ) Hódmezővásárhely, Mindszent és Székkutas településeken a közműves ivóvízellátás, továbbá a közműves szennyvízelvezetés és -tisztítás tevékenység végzésére az ARV-t mint közérdekü üzemeltetőt jelölte ki 2013. szeptember 1. és 2014. augusztus 31. között. ${ }^{80}$ Jelen ügyben a közérdekű üzemeltetőként történő kijelölés egyik érdekessége, hogy a kijelölés időpontjában még egy szolgáltató sem rendelkezett működési engedéllyel. A gordiuszi csomót a MEKH a következő érveléssel oldotta fel: „Tekintettel arra, hogy az ellátásbiztonság fenntartása érdekében a Hivatal azonnali beavatkozása vált szükségessé, a kizárólagosan állami tulajdonban álló víziközmü-szolgáltatókkal tárgyalás folytatására nem volt lehetőség; a víziközmü-szolgáltatás a Vhr. 17. § (13) bek. ${ }^{81}$ szerinti víziközmü-szolgáltatókkal

78 A MEKH 1642/2013. sz., 2013. 08. 22-én kelt határozata.

$79 \mathrm{Az}$ indoklásban a MEKH a Hódmezővásárhely polgármestere által adott tájékoztatásra hivatkozik. Lásd továbbá a Csongrád Megyei Bíróság [Szegedi Törvényszék] 16.Fpk.06-13-000524/13. sz. végzését a felszámolás megindításának közzétételéről; http://www.zsigmondy.hu/Document/vegzes_felszamolas_ meginditasanak_kozzetetelerol.pdf (2014. 01. 12.).

80 A közérdekü üzemeltetőként való kijelölés során lásd különösen: Vksztv. 32. § (1) bek. a) és b) pontjai, Vhr. 17. § (8) bek.; majd Vksztv. 32. § (2) bek., Vhr. 17. § (10), (12)-(14) bekezdések.

81 E jogszabályhely értelmében közérdekű üzemeltetőként elsődlegesen kizárólagosan állami tulajdonban álló víziközmü-szolgáltató jöhet számításba. 
nem volt biztositható. Figyelemmel továbbá arra, hogy a Hivatal előtt a víziközmüszolgáltatók müködési engedély iránti kérelmeire indult eljárások még folyamatban vannak és jelenleg müködési engedéllyel szolgáltató nincsen, a Hivatal az átmeneti időszakban - a felhasználók biztonságos víziközmü-szolgáltatáshoz jutására, valamint a Vksztv. 82. § (2) bek.-re tekintettel - ideiglenesen jelölte ki az ARV-t." ${ }^{\prime 2}$ A MEKH döntésénél, a Vhr. 17. § (12) bek. részletezett öt szempont - nevezetesen az ellátási terület földrajzi elhelyezkedése, az alkalmazott technológiai megoldások, a kijelölést megalapozó hiányosságok, a felmerülő költségek, a szükséges előkészület időigénye - mérlegelésén túl, „különös súllyal” számítottak még például a következő indokok: (a) az ARV a müködési engedély iránt benyújtott kérelméhez csatolt, 2013. május 23-án kelt nyilatkozatában vállalta a közérdekü üzemeltetőként való kijelölést, (b) az ARV a 2013. május 23-án müködési engedély iránt benyújtott kérelmére tekintettel tevékenységét a Vksztv. 82. § (2) bek. alapján a kérelem jogerős elbírálásáig gyakorolhatja; (c) az ARV az érintett települések vonatkozásában rendelkezik érvényes, későbbi - hivatali jóváhagyáshoz kötött - időpontban hatályba lépő üzemeltetési szerződéssel. Utóbbi szerződések kapcsán a MEKH kiemelte, hogy amennyiben ezen üzemeltetési szerződéseket jóváhagyja, és azok hatálybalépése megtörténik, úgy a Vhr. 19. § (1) bek. alapján a közérdekü üzemeltetői tevékenység határozattal megszüntetésre kerülhet.

\subsection{A víziközmü-szolgáltatók integrációjának egyéb feltételei}

A felhasználói egyenértéken túl több más szabály is szolgálja a víziközmű-szolgáltatók hatékony integrációját (például a kiszervezésre vonatkozó előírások; 83 lásd a Vhr. 33. §-át). Ezek közül a magunk részéröl fontosnak tartjuk kiemelni a fentebb már említett, az ellátási terület egybefüggőségére vonatkozó rendelkezéseket, ${ }^{84}$ amelyek a 40 km-en belül található vízmüvek integrációját hivatottak segíteni. A vonatkozó jogszabályhely nem követeli meg az ellátási terület megszakítástól mentes egybefüggőségét, pusztán azt, hogy a különálló területek egymástól való távolsága a 40 km-t ne haladja meg. A MEKH eljárásából például kitünik, hogy a Borsodvíz ellátási területe nem egybefüggő, azonban 40 km-en belüli, így az elöírásoknak meg-

82 A MEKH 1642/2013. sz. határozata.

83 Lásd a Pannon-víz esetét.

84 Vhr. 32. § „(1) A víziközmü-szolgáltatás hatékony üzemszervezési feltételeinek megteremtése érdekében, a Hivatal vizsgálja az engedélyezéssel érintett ellátási terület egybefüggőségét, az üzemeltetés hatékonyságát és mérlegeli annak hatásait. A Hivatal nem ad a kérelmezőnek müködési engedélyt az ellátási területként megjelölt települést vagy településeket közvetlenül ellátó víziközmü-rendszerek üzemeltetésére, amennyiben: a) az így létrehozható ellátási terület a kérelmezö kérelmében további ellátási területként megjelölt, vagy a már - engedély alapján fennálló - üzemeltetési területét képező, földrajzilag vele nem összefüggő ellátási területtől az üzemeltetés hatékonyságát elnehezítő távolságra fekszik, és b) ott az üzemeltetni kivánt víziközmü-rendszerekre nézve a Hivatal által elismert felhasználói egyenérték nem éri el a 100000 -et. (2) A Hivatal nem mérlegelheti az egymással földrajzilag össze nem függő ellátási területek közötti távolságoknak az üzemeltetés hatékonyságára gyakorolt hatását, amennyiben a különálló ellátási területek egymáshoz legközelebb eső települései közúton, a belterületi határaiktól számítottan 40 km-t meghaladó távolságra fekszenek." 
felel. Ezzel szemben a TRV működési engedély megszerzésére irányuló kérelme kapcsán két település vonatkozásában a MEKH azért tagadta meg a működési engedély kiadását, mivel azok kapcsán az egybefüggőségi szabály sérelmét állapította meg. Fontos megjegyezni, hogy a TRV ellátási területe e két településen túl sem volt egybefüggő, mivel a TRV alapvetően két nagyobb összefüggő területtel rendelkezik, melyeken a felhasználói egyenértékek külön-külön meghaladják a 100 ezret, e területegységek közötti távolság azonban semmilyen ellátási nehézséget, zavart nem okoz, mivel azok mind a tárgyi eszközök, mind a humánerőforrás tekintetében önállóan is müködőképesek, önálló üzemigazgatóságok (vagyis az üzemigazgatóságok által használt eszközöket és szakembereket nem szükséges egymás között megosztva átcsoportosítani). A kérelemben szereplő két településből (Újtikos, Tiszagyulaháza egység) álló, szigetszerü víziközmürendszer ugyanakkor mindkét nagyobb egybefüggő ellátási területtől $40 \mathrm{~km}$-t meghaladó távolságra fekszik. A MEKH így ezek vonatkozásában nem adott müködési engedélyt, vagyis a kérelmet ezen részében elutasította.

\section{3. Összegzés}

A jelen tanulmányban vizsgált integrációs folyamatok szorosan kapcsolódnak egyebek mellett - a víziközmüvek államosításához, illetve (re)municipalizációjához. Utóbbi kapcsán fontosnak tartjuk megjegyezni, hogy Magyarországon a Vksztv. (Nvtv.) szabályozása alapján a szükebb értelemben vett - vagyis a pusztán tulajdonjogi kérdéseket magában foglaló - remunicipalizációban az önkormányzatok nagyobb teret kaptak, mint korábban, vagyis tulajdont szereztek vissza. A tulajdonjogi kérdéseken túlmutató, egyéb szerepvállalási formákat is magában foglaló, tágabb értelmében vett municipalizáció szempontjából ugyanakkor eltérő a tendencia, amennyiben az önkormányzatoktól - a Vksztv. rendelkezései alapján - számos (pl. az árhatósági) funkció, feladat az államhoz került át.

Az integráció kapcsán fontosnak tartjuk kiemelni, hogy az még nem zárult le, a folyamat végéröl csak egy-két év múlva értekezhetünk. Mindazonáltal az integráció első köre is majd egytizedére csökkentette a víziközmű-szolgáltatók számát. Ebböl a szempontból az integráció eszközéül választott felhasználói egyenérték, illetve egyéb feltételek (az ellátási terület egybefüggősége, a személyi állománynyal szemben támasztott követelmények etc.), valamint mindezeknek egy müködési engedélyezési eljárásban történő érvényesítése (illetve a közérdekü üzemeltető intézménye) megfelelő alapot biztosítottak az integráció jogállami keretek között történő, biztonságos megvalósításához. Fontos kiemelni, hogy az integrációs folyamat szabályozásánál a jogalkotó az integráció mikéntjének és formájának megválasztásában (például a partnerválasztásban) az ellátásért felelősök részére relatíve nagy szabadságot biztosított.

Az integráció Vksztv. által támogatott formájának indokaként a döntéshozó és a végrehajtó elsődlegesen a hatékonyság magasabb fokának elérését hangsúlyozta, továbbá azon célt, hogy az országban a víziközmü-szolgáltatás színvonala egységesen magas legyen. A környezetvédelmi szempontok kevésbé kerültek kiemelésre 
(miközben a Vksztv. alapelvei között ilyenek is nevesítésre kerültek; lásd például a költségmegtérülés elvét vagy a szennyező fizet elvét), mindazonáltal mindez nem jelenti azt, hogy az integráció nem szolgálhatná a környezetvédelem érdekeit is. Ennek eldöntése érdekében többek között annak mérlegelése szükséges, hogy a hatékonysági szempontok között mennyiben engednek teret a környezeti szolgáltatások értékelésének. Fontos szempont lehet továbbá az is, hogy bár az országban a közműves ivóvízellátás aránya magas, ezzel szemben a közműves szennyvízelvezetés és -tisztítás még fejlesztésre szorul. Meglátásunk szerint az integráció folyamata hozzájárulhat ahhoz, hogy a szükséges fejlesztések megvalósuljanak, továbbá hogy a szintén égető fontosságú fenntartási munkálatok megtörténhessenek. $S$ hogy mindez milyen áron valósulhat meg? Nos, részleteiben, ez már egy következő tanulmány témája, annyi azonban mindenképpen rögzítendő, hogy amennyiben nem sikerül az infrastruktúra rekonstrukciójára több pénzt fordítani, akkor maga az integráció is csak egy jó irányba tett, de a cél elérésére önmagában alkalmatlan lépés lesz.

\begin{abstract}
The present article focuses on the integration of water utility supplier operated public water utility supplies in Hungary. According to the new Hungarian law (namely Act CCIX of 2011 on water utility supplies), the integration is merely one element of the instruments of the decision-makers to achieve their goals. According to the preamble of the act, the goals are the followings: to establish the basic rights and obligations of water utility supply, to protect national water utility property, to provide sustainable development in water utility sectors, to fulfil the objectives of the protection of drinking water resources and to ensure the conditions of water utility supply serving the extensive promotion of consumer protection, furthermore to ensure the implementation of these objectives by detached and transparent regulations. Expectedly, the procedure will be finished only by 2016, however, the number of water utility suppliers having existed before the adoption of the new law (i. e. circa 400 suppliers) has been reduced to approximately one-tenth by begin of 2014.
\end{abstract}

